\title{
Commitment to non-commitment: The role of a foundation in configuring a cross-sector collaborative space
}

Jonathan Schmidt, Ph.D. Fellow, Department of Organization, Copenhagen Business School

Cross-sector collaborative spaces have been suggested to provide a way of organising collaboration between the public, private, and third sector to address so-called grand challenges. However, due to the complexity and uncertainty of grand challenges, establishing collaborative spaces is associated with considerable risks. Innovation policy scholars disagree whether public or third sector organisations are better suited to take these risks. Based on the case of Copenhagen-based BLOXHUB, this paper investigates the role of a third sector organisation in interweaving actors across sectors to configure a collaborative space in the field of sustainable urban development.

Introduction

Collaboration between the public, private, and third sector is widely recognised to be crucial in addressing societal grand challenges, such as those documented by the United Nations' Sustainable Development Goals (United Nations General Assembly 2015). Hence, encouraging cross-sector collaboration is a main concern of challenge-oriented innovation policy (Kuhlmann and Rip 2018; Mazzucato 2018; Schot and Steinmueller 2016; Leijten et al. 2012; Rip and Joly 2012). Various forms of collaborative spaces have been suggested that are supposed to "allow diverse and heterogeneous actors to interact constructively over prolonged timespans" (Ferraro, Etzion and Gehman 2015, 373). However, less is known about the processes by which they become established.

In the field of sustainable urban development, recent years have seen the establishment of several collaborative spaces across Europe. While they differ significantly in their organisational governance, design, and activities, these spaces share an ambition to address the societal grand challenge of sustainable urban development by facilitating cross-sector, collaborative innovation involving actors from the public, private, and third sector. Examples include Barcelona Urban Lab (founded in 2008), London's Future Cities Catapult (2013), and Amsterdam's AMS-Institute (2013). These spaces have all been established under the leadership of city or national governments, whereby they seemingly follow the concept of the 'entrepreneurial state' (Mazzucato 
2018, 2013), taking the risk of facilitating collaboration on behalf of the private sector. In contrast, other scholars hint towards a more pronounced role for the third sector in facilitating collaboration through the establishment of collaborative spaces (Kuhlmann and Rip 2018; Leijten et al. 2012; Rip and Joly 2012).

BLOXHUB, co-founded and financed by the philanthropic foundation Realdania, provides an empirical case to explore the establishment of a collaborative space by a third sector organisation in Copenhagen, Denmark. Based on an abductive case study of BLOXHUB, this paper investigates the role of Realdania in the establishment of a collaborative space between the public, private, and third sector. First of all, an overview of the theoretical concepts is provided. Secondly, the methodological approach, data, and analytical strategy are described. Thirdly, the analysis follows the establishment of BLOXHUB as a collaborative space between the public, private, and third sector, focusing on the role of Realdania as a third sector organisation. Lastly, it is discussed how Realdania's commitment to non-commitment features in a cascade of events that leads to the establishment of BLOXHUB.

\section{Spaces for Cross-sector Collaborative Innovation to Address Grand Challenges}

Innovation policy scholars and practitioners alike call for mission- or challenge-oriented innovation policies as a response to grand challenges (Mazzucato 2018; Schot and Steinmueller 2016; Leijten et al. 2012). Challenge-oriented innovation policies do no longer perceive innovation merely as a driver of economic growth, providing indirect societal benefits in the form of tax revenues and employment. Instead, they consider innovation as a direct means to address societal grand challenges. At the same time, the complexity of grand challenges implies that the government is increasingly less able to formulate innovation priorities. Innovation policy may only incentivise engagement in the search for solutions, not its outcomes. Identifying the right approaches demands new forms of 'symbiotic partnerships' between public, private, and third sector, yet "how to design, implement and govern [them] remains far from clear" (Schot and Steinmueller 2016, 20). In order to find novel ways to organise cross-sector collaboration, a better understanding of the nature of grand challenges is required.

Ferraro, Etzion, and Gehman (2015) have shown grand challenges to be complex, uncertain, and evaluative. Due to grand challenges' complexity, actors addressing them are unable to grasp the entire system and instead rely on local actions without an overview of their aggregated effects. Accordingly, unintended consequences of actions addressing grand challenges are to be expected. Alleged solutions frequently expose or create further problems, in turn requiring adjustment of the initial solution. Second, grand challenges are characterised by Knightian uncertainty (cf. Knight 1921). Actors are neither able to predict future states of the world nor assign probabilities to them. In addition, actors' preferences are evolving and inconsistent. A future state deemed desirable at one point, may not be in the future. Third, grand challenges are evaluative, cutting across 
conventional professional and epistemic boundaries. They are "caught up in processes of continual reconfiguration, depending on whom and what becomes associated with them" (Ferraro, Etzion and Gehman 2015, 367), because different actors approach them with variable ontologies (cf. Callon 1998). The complex, uncertain, and evaluative nature of grand challenges makes it difficult to take collective action, as for instance, international climate policy negotiations have shown throughout the past decades (Ansari, Wijen and Gray 2013).

The complexity and uncertainty of grand challenges make it advisable for actors to take potentially reversible actions. In response, Ferraro et al. (2015) suggest the sociological concept of 'robust action' as an organising strategy. Originally formulated by Leifer (1991), the concept was introduced into organisation and management studies by Eccles and Nohria $(1992,11)$, who defined it as "action that accomplishes short-term objectives while preserving long-term flexibility. Because future problems and opportunities are always uncertain, present actions should not constrict a manager's ability to adapt to new situations as they evolve". In short, robust action refers to "noncommittal actions that keep future lines of action open" (Padgett and Powell 2012, 24). Applied to the case of grand challenges, Ferraro et al. (2015) emphasise that robust action needs to be organised in a distributed fashion across multiple actors with differing views and interests.

Innovation policy and organisation scholars suggest similar ideas for cross-sector collaborative spaces to organise robust action despite the uncertainty and complexity of grand challenges. In organisation studies, Ferraro et al. (2015) argue that organising collaboration requires 'participatory architectures', which ensure long-term engagement of heterogeneous actors despite their divergent evaluation criteria and interests. Participatory architectures provide a space where actors can meaningfully interact, even though their relations may be publicly adversarial. In innovation policy studies, the concept of 'tentative governance' "aims at creating spaces for probing and learning instead of stipulating options for actors, institutions, and processes" (Kuhlmann and Rip 2018 , 4). Others call for 'negotiation spaces' which capture alternative imaginations and democratise control over innovation production (Schot and Steinmueller 2016, 18). Importantly, Rip and Joly (2012) emphasise that cross-sector collaborative spaces are to be established in existing configurations of the public, private, and third sector. It requires 'policy entrepreneurs', who propose, initiate, and create openings for the establishment of collaborative spaces in these configurations.

Innovation policy scholars disagree whether public or third sector organisations are better suited to take the role of establishing and facilitating cross-sector collaborative innovation spaces. On the one hand, Mazzucato's (2013) widely received theory of the 'entrepreneurial state' suggests that government has a central role in facilitating collaborative innovation. A recent report to the European Commission emphatically extends this role to the context of challenge-led innovation policies (Mazzucato 2018). On the other hand, scholars point towards a possible coordinating role for third sector organisations, in cross-sector collaborative innovation addressing grand challenges 
(Kuhlmann and Rip 2018; Schot and Steinmueller 2016; Leijten et al. 2012; Rip and Joly 2012). Especially charitable foundations may take a role as "intermediary organizations [...] to enable and improve concerted action without having a master plan" (Kuhlmann and Rip 2018,4), combining flexibility and long-term orientation with a tendency to focus on the public interest.

While the policy process and innovation policy instruments on the government's part are well known (Borrás and Edquist 2013), less is known about the characteristics of the third sector in general and charitable foundations in particular, which may make them apt for such a role as 'policy entrepreneurs' between public, private and, third sector. For instance, Prewitt $(2006,370)$ finds that "[w]e know much more about how foundations came to be than what they accomplish". In order to address this shortcoming, this study follows how a specific foundation accomplishes the establishment of a collaborative space, building on existing literature on the role of the third sector and foundations.

\section{The Third Sector and the Role of Philanthropic Foundations}

The third sector is commonly defined in contrast to the public and private sector, operating in a space which is either considered to be 'allowed' or 'claimed' (Prewitt 2006). According to the economic 'three-failures theory', the third sector is 'allowed' in so far as it operates only in those areas, which neither the public nor the private sector covers (Steinberg 2006). As a starting point, the private sector is assumed to meet customer demands well under two conditions. Firstly, customers must be well informed about their purchase as well as about the adequate quality and quantity of a given good, secondly, consumption is individual, rather than collective. Violations of the first condition are typically compensated by the third sector ('contract failure'), while the public sector tends to cover unmet demands in case of the second condition's violation ('market failure'). Meanwhile, in democratic countries, distribution of public resources is indirectly subject to the will of the majority. As a result, collective goods demanded by minorities will remain unsupplied ('government failure'). Through donations and voluntary work, this minority may work towards the provision of these goods in the third sector. A lack of resources and professionalism can lead to a poor provision of goods in the third sector ('voluntary failure'), ultimately calling the public and private sector into action again.

According to the second rationale the third sector claims its operating space. Third sector organisations are assumed to possess unique resources based on which they contest the boundaries of the public and private sector. Charitable foundations occupy a special position in negotiating the boundaries of the third sector, which derives from their defining feature, "a permanent endowment, not committed to a particular institution or activity, that provides a grant-making capacity reaching across multiple purposes and into the indefinite future" (Prewitt 2006, 355). Their financial independence places them "among the freest institutions in modern societies: free in the sense of being independent of market forces and the popular political will", which allows foundations "to ignore 
political, disciplinary and professional boundaries, if they choose, and to take risks and consider approaches others cannot" (Anheier and Daly 2007, 4). Their freedom makes foundations subject to ongoing accountability claims for projecting their vision of the public good onto society. Historical examples show states growing uncomfortable with foundations' power, investigating and even closing them if they become too political (Prewitt 2006).

While the third sector receives the vast majority of its funding from other sources, it is the main destination for foundations' grant-making and activities (Prewitt 2006). The natural relation of charitable foundations with the third sector makes it even more relevant to consider the special circumstances under which charitable foundations may support the public and private sector. Support to a public sector organisation typically enables them to engage in activities precluded by their budget, yet desired by the foundation, such as "co-sponsoring a commission to examine a major social issue"; meanwhile, a grant to a private sector organisation "might persuade it to operate at odds with market forces" (Prewitt 2006, 357). Both of these funding decisions are prone to alter the boundaries between sectors.

Since the beginning of the 2000s, philanthropies are increasingly swaying from mere social service delivery to social action and change (Schuyt 2010), transgressing from 'allowed' space into 'claimed' space. Foundations' novel practices, assumptions, and beliefs are subsumed under the concept of 'venture philanthropy' (Mair and Hehenberger 2013, 1175): Whereas traditional philanthropy would focus solely on grant-making, venture philanthropy prescribes investments and activities and gets actively involved in them, trying to improve the efficiency and effectiveness of social organisations and expecting explicit social, and often also financial, returns on investment. Frequently, these outcomes are achieved by "design[ing] an integrated cluster of grants, given over an extended time frame, with a clear goal in mind [for which they] seek out institutions that will ensure that this goal is reached, and when such do not exist, to create them" (Prewitt 2006, 363). In a double sense, innovation features central in the concept of venture philanthropy, particularly among Danish foundations: on the one hand, doing things differently is integral to foundations' self-understanding; on the other hand, they aim to facilitate the innovative activities of other actors to promote societal changes (Habermann 2007). For instance, this study will show how Realdania devised BLOXHUB as an organisational innovation to facilitate other actors' innovations in order to reach the goal of sustainable urban development.

\section{Methodological considerations}

Inductive case studies have been described as particularly suited for theory building in the context of grand challenges, aiming to build an emergent theoretical understanding through deep immersion (Eisenhardt, Graebner and Sonenshein 2016). In the given case, emergent theoretical understandings of the field under study already exist, yet require 
further specification. Novel forms of collaboration between public, private, and third sector are considered integral to challenge-led innovation policies (Kuhlmann and Rip 2018; Mazzucato 2018; Schot and Steinmueller 2016; Leijten et al. 2012), however little is known about how they become configured between sectors. Whereas some claim a continued leadership role for the government (Mazzucato 2018, 2013), others point towards a coordinating function for third sector organisations (Kuhlmann and Rip 2018; Leijten et al. 2012). Therefore, rather than working purely inductively, this study takes an abductive approach (Alvesson and Kärreman 2007; Locke, Golden-Biddle and Feldman 2008; Mantere and Ketokivi 2013), shifting back and forth between these existing theoretical concepts and empirical exploration.

While the public sector had a lead role in the establishment of most cross-sector collaborative spaces in the field of sustainable urban development across Europe, the empirical case of BLOXHUB provides an opportunity to study the role of a philanthropic foundation in the establishment of a collaborative space between the public, private and third sector in Denmark. As a theoretically informed sample (Eisenhardt and Graebner 2007), the case study has the potential to specify and extend relationships between existing theoretical concepts. In order to conceptualise empirical observations of Realdania's role theoretically, the study refers to literature on the third sector and charitable foundations (Mair and Hehenberger 2013; Habermann 2007; Powell and Steinberg 2006), thereby aiming to specify the coordinative role of third sector organisations in cross-sector collaborations, which innovation policy scholars have so far only indicated (Kuhlmann and Rip 2018; Leijten et al. 2012).

The data for this study stems from the author's ethnographic fieldwork in and around the BLOX building over a period of 18 months from December 2016 to August 2018. The data entails field notes, including informal conversations with the staff of BLOXHUB's residents, members, and affiliated organisations; participant observation of a variety of events and activities, as well as internal and publicly accessible documents, such as strategy presentations, minutes of meeting, and press releases. Through these data, the analysis follows firstly how BLOXHUB emerged in the context of the BLOX building. The reported events cover the period from 2005 until 2018. Secondly, the analysis provides an overview of BLOXHUB's governance, organisational design, and activities, as well as comparing these with other collaborative spaces in Denmark. Combined, these analyses shed light on the role of philanthropic foundation Realdania as a third sector organisation in configuring a collaborative space between the public, private, and third sector.

Realdania, a Philanthropic Foundation focused on the Built Environment

In order to follow and assess Realdania's role in the establishment of BLOXHUB, an overview of the third sector organisation's background and ambitions is helpful. Realdania is a philanthropic foundation, whose mission is "to improve the quality of life 
and benefit the common good by improving the built environment" (Realdania 2018b). The philanthropy is governed as a member-based association that emerged in 2000 from a mortgage credit association selling off its mortgage-credit activities as part of the merger between Realkredit Danmark and Danske Bank. After the sale, the members decided to secure the assets and use the return of its financial investments to support philanthropic projects in the built environment. Any real estate owner in Denmark can become a member of Realdania, and it currently has 150,000 members. Realdania's total equity of 22.6 billion DDK at year-end 2017 places it among Denmark's largest foundations by endowment.

During the period covered by this study, Realdania adopted a venture philanthropist approach along with an increasing focus on sustainability. In 2011, Realdania joined the UN Global Compact initiative encouraging organisations to adopt sustainable and socially responsible policies, and report implementation status. The emphasis on sustainability was intensified in 2013 when Realdania and UN Global Compact announced a partnership to engage philanthropy in the corporate sustainability movement. In its new strategy issued the same year, Realdania adopted an 'activist' strategy (Erhardtsen 2013), reflecting the main tenets of 'venture philanthropy' (Mair and Hehenberger 2013). However, an ambitious agenda seems to have been prevalent in the organisation even prior to this period, as this quote by an anonymous Realdania representative indicates: "[I]n ten years' time we want people to say that Denmark would not have looked this way if it had not been for us" (Habermann 2007, 136).

\section{Configuring BLOXHUB between Public, Private, and Third Sector}

The following section chronologically traces the events leading to the establishment of BLOXHUB. Special attention is given to the interplay of actors across sectors, revealing several interdependent conditions for the emergence of BLOXHUB.

The genesis of BLOXHUB takes its starting point in Realdania's acquisition of the site of a former brewhouse from the City of Copenhagen (hereafter: the City) in 2006, complemented by the purchase of Fæstningens Materialgaard, a neighbouring ensemble of historic military depot buildings in 2007. Located in close proximity to the Royal Library, the National Museum, and the Danish parliament, the site represents one of Copenhagen's most attractive remaining waterfront locations. The planned multifunctional building's intended use, and the City's condition for the sale to Realdania, was primarily to provide a new home for the Danish Architecture Centre (hereafter: DAC) and its exhibition space, along with apartments, offices, as well as a café and restaurant. Following an invited interview-based competition, Realdania announced Rem Koolhaas' Office for Metropolitan Architecture (OMA) as the winning architect in April 2008, and construction started in 2013. At that time, there was no mentioning of the collaborative space it houses today. 
The idea to include a collaborative space in the building was first brought into play by an expert panel on economic growth in the creative industries, appointed by the Ministry of Industry, Business and Financial Affairs (hereafter: the Ministry). In its final report in 2013, it proposed to turn Realdania's building project into a "lighthouse for Danish urban development, architecture and design" (Erhvervsministeriet 2013), which would highlight Danish industry's strengths in these fields. The initial intention behind the Ministry's suggestion was solely to support economic growth and exports, it seems, rather than addressing sustainable urban development. In fact, at the time of its proposal in 2013, the Ministry's official name was still the 'Ministry of Business and Growth', only changing to its current name in 2016.

Even though initially displeased with such uninvited advice, Realdania's board adopted, and began to develop the idea after some time. At first, DAC was tasked with further developing this concept. Yet in mid-2014, Realdania's management decided to take the project into their own hands and establish the collaborative space as an independent organisation that was to become BLOXHUB. Subsequently, they invited the City and the Ministry to become co-founders. Effectively, the Ministry commissioned Realdania with the implementation of its envisioned policy; albeit a policy, which it could not have implemented itself in lack of the physical space and financial resources at the heart of it.

\begin{tabular}{|c|c|c|c|c|}
\hline Institution & Level & BLOXHUB & $\begin{array}{c}\text { Danish } \\
\text { Architecture } \\
\text { Centre (DAC) }\end{array}$ & $\begin{array}{c}\text { Design Society } \\
\text { (Danish Design } \\
\text { Centre, Index, } \\
\text { Global Fashion } \\
\text { Agenda) }\end{array}$ \\
\hline Realdania & Civil society & $\begin{array}{l}\text { Co-founder/ } \\
\text { Financing }\end{array}$ & Financing & \\
\hline $\begin{array}{l}\text { Ministry of Industry, } \\
\text { Business, and } \\
\text { Financial Affairs }\end{array}$ & National gov. & Co-founder & Financing & Financing \\
\hline Ministry of Culture & National gov. & & Financing & \\
\hline $\begin{array}{l}\text { Ministry of } \\
\text { Transport, Building, } \\
\text { and Housing }\end{array}$ & National gov. & & Financing & \\
\hline $\begin{array}{l}\text { The Capital Region } \\
\text { of Denmark }\end{array}$ & Regional gov. & & & Financing \\
\hline City of Copenhagen & Municipal gov. & Co-founder & & \\
\hline
\end{tabular}

Figure 1: Shared founding and financing relationships of BLOX anchor tenants

The emerging shared interests of the Ministry and Realdania equally shaped the constellation of the BLOX building's anchor tenants (see Figure 1): BLOXHUB, the DAC and the Design Society (an umbrella for three design-oriented organisations: Danish Design Centre, Global Fashion Agenda, INDEX - Design to Improve Life)). Realdania 
finances both BLOXHUB and DAC, while the Ministry of Industry, Business and Financial Affairs co-finances DAC as well as the Design Society. With two further ministries as financing partners of DAC, the Capital Region of Denmark backing the Design Society, and the City as a co-founder of BLOXHUB, all levels of the Danish government are involved in the BLOX environment. This troika of semi-public actors, comprising BLOXHUB, DAC, and the Design Society, provides the backbone for the building's aspiration to be "Denmark's world of architecture, design and new ideas" (BLOX 2018), interweaving third and public sector based on prior existing financing commitments.

Realdania, the City of Copenhagen, and the Danish Ministry of Industry, Business and Financial Affairs co-founded BLOXHUB in June 2016 as a non-profit, membershipbased association for companies, research institutions, municipalities, and other relevant public and private organisations (BLOXHUB General Meeting 2016). On its website, Realdania explains the rationale for BLOXHUB's establishment as follows:

BLOXHUB is Denmark's new base for the urban solutions of the future with a co-working space in the heart of Copenhagen, and an international network entailing companies, organizations and researchers within urbanization. [...] The starting point for BLOXHUB's establishment is the need for collaboration between architecture, tech, design, construction and urban planning in order to address the challenges of global urbanization and climate change. Through building an ecosystem of actors within urban development, BLOXHUB creates ideal circumstances for sharing and scaling solutions for cities for people. (Realdania 2018a)

Apart from financing the BLOX building, Realdania has committed to support BLOXHUB's basic operational costs with 130 million DKK over a period of 10 years from 2018-2027, including reduced rent (BLOXHUB Annual Report 2016). To the author's knowledge, the Ministry is for the time being a nominal co-founder without financial obligations, while the City of Copenhagen's current financial contribution is limited to the rental costs for its urban innovation unit Copenhagen Solutions Lab, which is a BLOXHUB resident member. BLOXHUB's two other income streams are the rents paid by its resident members and membership fees. In 2017, Realdania's annual cash support of BLOXHUB amounted to one-third of the Ministry's budget for support of innovation and entrepreneurship or one-fifth if the Ministry's support to design-related initiatives is included (Finansministeriet 2017, §8). However, the Ministry's design budget mostly supports the Design Society, therewith equalling an implicit additional support to the BLOX environment.

In summary, the emergence of BLOXHUB as a collaborative space is traceable to multiple necessary, yet individually not sufficient, conditions. Several actors and their decisions mutually conditioned each other. These include Realdania's decision to invest 
into a landmark building; the City's willingness to sell the plot of land; the Ministry's recommendation to establish a lighthouse to increase the international visibility of an already globally recognised Danish industry; finally, Realdania's adaptation and implementation of this endeavour, becoming the foundations' largest investment to date. In an interview with a major Danish newspaper soon after the official opening of the BLOX building and BLOXHUB in May 2018, Realdania's CEO Jesper Nygård answered a self-posed question: "Would we have done it today? Hardly. [...] Will we do something of this size again? Not in my time, not even if I was 20 years younger" (Benner 2018). Crucially, not only their mutual presence but also their temporal order and interplay turned necessary into sufficient conditions.

\section{BLOXHUB's Governance, Organisational Design, and Activities}

The following section attends to BLOXHUB's governance structure, organisational design, and activities in order to shed light on its configuration between the public, private, and third sector. Subsequently, the specificities of BLOXHUB's configuration are highlighted through a comparison with other collaborative spaces in Denmark.

BLOXHUB is supervised by a board comprising nine members, three of which are assigned by the founding organisations and six elected by the General Meeting of association members. The board appoints a managing director to head the BLOXHUB secretariat and take responsibility for the collaborative space's operations. As of August 2018, the BLOXHUB association had 203 community members of which 45 were resident members. Approximately two-thirds of both members and resident members are private companies from a broad range of industries, including architecture, civil engineering, and construction as well as building materials. Member organisations from the public sector include universities and applied research institutions, municipalities, as well as the City of Copenhagen's urban innovation lab. A number of network organisations and associations, as well as a few advocacy organisations, represent the third sector.

For the resident members, BLOXHUB serves above all as a co-working space offering serviced office and meeting facilities. In total, BLOXHUB occupies a floor area of over 10,000 $\mathrm{m}^{2}$ across 1.5 floors of the BLOX building and neighbouring Fæstningens Materialgaard, providing space for more than 550 desks. For all members, BLOXHUB offers a variety of events and innovation activities (see Figure 2 for an overview). As a principle, the BLOXHUB secretariat refrains from taking a lead role in defining concrete innovation projects, insisting that the members should come up with own ideas for events and workshops, while BLOXHUB offers space as well as support in the practical organisation and promotion of activities. Hence, the provided overview is only indicative, and the offered range of activities will continue to evolve. 


\begin{tabular}{|l|l|}
\hline Mornings & $\begin{array}{l}\text { Morning sessions, where usually three speakers share their perspective on } \\
\text { a trending topic within sustainable urban development, followed by a short } \\
\text { discussion }\end{array}$ \\
\hline Match & $\begin{array}{l}\text { Innovation sessions (2 sessions on directly following days or with up to } 3 \\
\text { weeks in between) gathering approximately } 10 \text { different organisations } \\
\text { around a certain innovation topic to brainstorm and explore possible } \\
\text { collaborations. The Match program is operated by Smith Innovation, a } \\
\text { consultancy firm specialised on innovation within the built environment }\end{array}$ \\
\hline Science Forum & $\begin{array}{l}\text { An industrial research network, organising transdisciplinary events and } \\
\text { conferences on various topics within sustainable urban development that } \\
\text { bring together interested professionals and academics across universities } \\
\text { and disciplines }\end{array}$ \\
\hline Accelerator & $\begin{array}{l}\text { Three months start-up accelerator program. First and so far, only edition ran } \\
\text { in fall } 2016 .\end{array}$ \\
\hline Pitch Salon & $\begin{array}{l}\text { Pitch sessions, where BLOXHUB members get an opportunity to obtain } \\
\text { feedback on a certain topic by an expert panel. }\end{array}$ \\
\hline
\end{tabular}

Figure 2: Overview of BLOXHUB's activities.

BLOXHUB's specific configuration becomes even clearer when comparing it with other collaborative spaces in Denmark. First, in contrast to internal innovation units (Puttick, Baeck and Colligan 2014; Tõnurist, Kattel and Lember 2017), such as Copenhagen Solutions Lab, MindLab or Innovationshuset, BLOXHUB does not take responsibility for innovation projects. These innovation units are internal to, set-up by, or funded by the government with the purpose of innovating policy or public service alongside shifting collaborators across sectors. Meanwhile, BLOXHUB is an independent organisation, and only supports other actors' innovation processes. Second, even though cooperating with neighbouring Copenhagen Street Lab, BLOXHUB is not an urban laboratory in the sense of a designated city district for experimentation (Karvonen and van Heur 2014). Third, BLOXHUB is backed by a philanthropic foundation and not by a corporation, distinguishing it for instance from Space10, IKEA's Copenhagen-based "secret innovation lab" (Le Pluart 2016).

In terms of similarities, BLOXHUB's configuration shares on the one hand characteristics with an innovation network or cluster. Examples of such third sector organisations include GATE21, a partnership between municipalities, companies, and knowledge institutions aiming to accelerate Greater Copenhagen's transition to green energy, or InnoBYG, a network of knowledge institutions and companies to improve sustainability in the construction industry, co-funded by the Ministry of Higher Education and Science. On the other hand, different from such networks, BLOXHUB's operation of a physical co-working space corresponds with the offering of commercial co-working space providers such as Symbion or Rainmaking Loft. BLOXHUB combines both types of collaborative spaces in one organisation. 
Various industry networks and commercial co-working spaces existed prior to BLOXHUB's establishment. Realdania could also have decided to support these existing ones; however, in the spirit of venture philanthropy, seems to believe in a higher impact of BLOXHUB's organisational design and strives for more managerial control over the grant-receiving organisation. In fact, BLOXHUB does not only combine features of existing collaborative spaces, but it also enters into competition with them. Without BLOXHUB's establishment, its members would probably have spent time and resources on other industry networks' activities and its residents would have rented desks elsewhere. Thus, while the public sector allowed and even demanded a collaborative space, BLOXHUB claims space from prior existing collaborative spaces across sectors. Presumably in order to include rather than displace them, several of these collaborative spaces have become BLOXHUB members, and BLOXHUB's management emphasises its function as a 'network of networks'.

\section{Realdania's Commitment to Non-Commitment}

The analysis has traced BLOXHUB's emergence as a cross-sector collaborative space to the temporal interplay of multiple necessary conditions, entailing actors from the public, private, and third sector. Combining an industry network with a commercial co-working space, BLOXHUB's organisational design showed to entail tenets of a third and private sector organisation. While third sector organisation Realdania emerged as a central actor in the process, its exact role in the configuration of BLOXHUB requires further specification. Was the collaborative space between sectors allowed or claimed (Prewitt 2006)? On the one hand, the three-failures theory (cf. Steinberg 2006) suggests that the establishment of the collaborative space under the aegis of Realdania can be attributed to the failure of the private and public sector to provide such a space. On the other hand, the concept of venture philanthropy (cf. Mair and Hehenberger 2013) may suggest that Realdania has claimed the collaborative space. These explanations will be considered in turn, to show how both mechanisms were at play in the case at hand.

According to the three-failures theory, the private sector's lacking provision of a cross-sector collaborative space to address the collective action problems arising from sustainable urban development can be considered a market failure. However, there seems to be no industry network with an associated co-working space focusing on sustainable urban development, let alone one that financially affords physical office space for public and third sector organisations. This is surprising as innovation policy scholars' agreement on the need for cross-sector collaboration indicates that the establishment of collaborative spaces should in principle make business sense. Three-failures theory would suggest that it is the responsibility of the government to compensate for such a collective action problem in addressing grand challenges.

Meanwhile, the government's inability to formulate innovation priorities in face of grand challenges' uncertainty and complexity results in a government failure. The 
public sector is in dire need of input from the private and third sector. Implicitly, innovation policy itself becomes a subject of innovation at BLOXHUB, bypassing the conventional policy process. Different from commercial co-working spaces, BLOXHUB seems to not solely aim at private-sector innovation, but also at innovation on the policy level, as the engagement of the City and the Ministry suggests. In fact, the Ministry itself recognises cross-sector collaborative spaces as a pathway to overcome its problems. However, the Ministry would neither have been able to justify the investment into a starchitect-designed landmark building like BLOX nor support the operating costs of BLOXHUB at the same level as Realdania. On the ropes with its current repertoire of innovation policy instruments, it seems that it considered this setup as an opportunity to leverage and catalyse Denmark's existing strengths in urban development.

At first glance, Realdania appears to simply enter an allowed space to establish BLOXHUB. However, the establishment of BLOXHUB as a new, independent organisation indicates that Realdania evaluated other third sector responses to the market and government failures as insufficient ('voluntary failure'). Even though various networks and organisations addressing sustainable urban development existed prior to BLOXHUB's establishment, Realdania chose not to invest in them, founding a novel organisation instead. Counterintuitively, even though public and private sector seem to allow and even demand third sector engagement, no third sector organisation has hitherto committed resources to a collaborative space at the level of Realdania. What held other third sector organisations from filling the allowed space, and why did Realdania decide differently?

In short, organisations from all three sectors refrain from providing a cross-sector collaborative space to address sustainable urban development. Considering the risk involved this is strategically advisable if we bear in mind the definition of robust action as "noncommittal actions that keep future lines of action open" (Padgett and Powell 2012, 24). Any actor investing resources in the establishment of a collaborative space is facing a principal-agent problem, under which the actor has to assume other actors to act robustly and not commit in the same way. This mutual non-commitment creates a deadlock. Even though actors across sectors recognise a cross-sector collaborative space to be mutually beneficial, no one commits the requisite resources. While the space is in principle allowed, someone needs to claim it, taking the associated risk of other actors' noncommitment into account.

In line with the premises of venture philanthropy (cf. Mair and Hehenberger 2013), Realdania's commitment breaks the deadlock while anticipating the risk of noncommitment in two ways. On the one hand, Realdania's investment acts as a physical placeholder in the cityscape for engagement with sustainable urban futures. If considered independent of its designated vision and purpose, the BLOX building is a property investment in a multi-use building in one of Copenhagen's most attractive remaining waterfront locations. Without doubt, numerous other commercial, for-profit property investors would have readily invested in this location. It is only by foregoing rental income and renting out to non-profit organisations - including the Design Society, DAC, 
and BLOXHUB - that Realdania opens a physical space, which otherwise would presumably have ended as a closed space, occupied by potent private sector tenants. By entering a physical, long run commitment, the building holds the time window open from which it emerged, affording future lines of action for other actors. Thereby, Realdania's commitment differs from traditional innovation policy programs, whose priorities can be relatively swiftly re-evaluated. BLOXHUB's material manifestation as a collaborative space opens for the possibility that it may take on a life of its own: the sustainable urban development agenda in Copenhagen is here to stay.

On the other hand, to ensure that the building takes on a life on its own between sectors, Realdania anchors its effort in its relationships with various levels of the Danish government: the co-funding of DAC and the Design Society, and the co-founding of BLOXHUB. Thereby, the third sector organisation's commitment implicitly secures the commitment of the public sector. The sheer size of Realdania's investment mobilises public funding in its aftermath. Due to the entanglement of interests in and around BLOX, with BLOXHUB as a central building block, it may be likened to a systemically important financial institution, which is considered too-big-too-fail due to its systemic interconnectedness (Financial Stability Board 2018). Public and private sector allow Realdania as a third sector organisation to establish a collaborative space, yet the bold way in which BLOX and BLOXHUB claim the allowed space safeguards the durability of the space's configuration between sectors.

The resulting intermingling of public and private sector innovation in a space with limited, membership-based access may raise criticism as it seemingly awards certain actors privileged access to democratic institutions and processes. Particularly, if "public support is involved (through subsidies and/or involvement of public labs) such collaborative spaces may be considered to blur the boundaries between public interest and private interest (up to abusing taxpayer's money) (Rip and Joly 2012, 7)". However, as research on open-source politics shows, "[o]pen spaces are not necessarily accessible to a large number of people [...]. Instead, openness signifies a lack of determination at the level of meaning. This is why open spaces invite imagination and provide conditions for change, while closed spaces do not" (Husted and Plesner 2017, 654). Put differently, openness should not be confounded with accessibility. In this sense, Realdania's commitment affords other actors' indeterminacy at the level of meaning.

Returning to the possible role of the third sector in the establishment of crosssector collaborative spaces, particularly compared to the public sector, it must be emphasised that BLOXHUB was not simply established by Realdania as a third sector organisation. Rather, venture philanthropy and the entrepreneurial state acted hand in hand to address the public and private sector's inability to provide a space for the exploration of robust, collective action. Taking the role of the venture capitalist in the name of the Ministry, Realdania provided the resources for an endeavour, which the Ministry otherwise would neither have been able to finance nor legitimate, at the same time securing continuity throughout political vagaries. Realdania's commitment affords other actors' non-commitment. Regardless of sector, they do not have to commit 
additional financial resources in order to explore novel collaborations within the field of sustainable urban development but can maintain their indeterminacy at the level of meaning.

Thereby, Realdania does not act robustly but lastingly exposes itself, as underlined by CEO Jesper Nygård's statement that, if he had to make the decision again today, he would probably not commit the resources in the same way. In fact, even if Realdania was to commit the resources again, it is unlikely the collaborative space would materialise in the same way. The analysis has shown that the time was ripe for BLOX and BLOXHUB. Padgett and Powell (2012, 26-28) describe such a situation as 'poisedness', by which they mean circumstances under which the social context is rich with potential and prone to the reception of an innovation and its subsequent reconfiguration by it. The collaborative space was established in a cascade, in which Realdania was far from being the only actor involved, and its claim of an allowed space served merely as a trigger. Realdania's commitment is the result of cascading transpositions of ideas and practices across the public, private, and third sector. Configuring a collaborative space to address grand challenges does not require filling an allowed or claiming a space between, but interweaving sectors, as the case of BLOXHUB shows.

Meanwhile, just as Realdania's commitment was in its establishment, BLOXHUB is only one in a number of necessary conditions in addressing sustainable urban development as a grand challenge. The interplay of several necessary conditions over time is needed if BLOXHUB is in fact to facilitate cross-sector collaborations that advance sustainable urban development. The City's recent decision to significantly reduce the budget of its urban innovation lab is but one of the decisions that, not alone, but in their interplay, may determine BLOXHUB's future fate and success as a crosssector collaborative space.

\section{References}

Alvesson, M. and Kärreman, D. (2007). Constructing mystery: empirical matters in theory development. The Academy of Management Review, vol. 32(4), pp.12651281.

Anheier, H. and Daly, S. (2007). The Politics of Foundations: A Comparative Analysis. New York, NY: Routledge.

Ansari, S. (Shaz), Wijen, F. and Gray, B. (2013). Constructing a Climate Change Logic: An Institutional Perspective on the "Tragedy of the Commons". Organization Science, vol. 24(4), pp.1014-1040.

Benner, T. (2018). Realdania: Vi havde ikke bygget Blox $i$ dag. [online] Politiken. Available at: https://politiken.dk/kultur/arkitektur/art6474412/Realdania-Vihavde-ikke-bygget-Blox-i-dag [Accessed 01.09.2018]

BLOX (2018). Vision for BLOX. [online] BLOX. Available at: http://www.blox.dk/english [Accessed 20.03.2018]. 
BLOXHUB General Meeting (2016). Articles of association for The BLOXHUB Association. Available at: http://cdn-bloxhuborg.pressidium.com/wp-content/ uploads/2017/01/Vedt\%C3\%A6gter-pa\%CC\%8A-engelsk_FINAL-ARTICLESOF-ASSOCIATION_24052016.pdf [Accessed 21.02. 2018].

Borrás, S. and Edquist, C. (2013). The choice of innovation policy instruments. Technological Forecasting and Social Change, vol. 80(8), pp.1513-1522.

Callon, M. (1998). An Essay on Framing and Overflowing: Economic Externalities Revisited by Sociology. The Sociological Review, vol. 46, pp.244-269.

Eccles, R.G. and Nohria, N. (1992). Beyond the hype: Rediscovering the essence of management. Boston, MA: Harvard Business School Press.

Eisenhardt, K.M. and Graebner, M.E. (2007). Theory Building from Cases: Opportunities and Challenges. The Academy of Management Journal, vol. 50(1), pp.25-32.

Eisenhardt, K.M., Graebner, M.E. and Sonenshein, S. (2016). Grand Challenges and Inductive Methods: Rigor without Rigor Mortis. Academy of Management Journal, vol. 59(4), pp.1113-1123.

Erhardtsen, B. (2013). Realdania med ny aktivistisk strategi. [online] Berlingske Business. Available at: https://www.business.dk/content/item/22487 [Accessed 09.08. 2018].

Erhvervsministeriet (2013). Danmark i arbejde. Vaekstplan for kreative erhverv.design. [online] Regeringen. Available at: https://em.dk/ /media/files/2013/07-02-13vaekstplan-kreative-erhverv.ashx?la=da [Accessed 09.10.2018]

Ferraro, F., Etzion, D. and Gehman, J. (2015). Tackling Grand Challenges Pragmatically: Robust Action Revisited. Organization Studies, vol. 36(3), pp.363-390.

Financial Stability Board (2018). Addressing SIFIs. [online] Available at: http://www.fsb.org/what-we-do/policy-development/systematically-importantfinancial-institutions-sifis/ [Accessed 09.10. 2018].

Finansministeriet (2017). Finanslov for finansåret 2017, $\S$ 8. Erhvervs- og Voekstministeriet. [online] Finansministeriet. Available at: https://www.fm.dk /publikationer/2017/finanslov-for-2017 [Accessed 03.09.2018].

Habermann, U. (2007). Denmark. In: H. Anheier and S. Daly, eds., The Politics of Foundations: A Comparative Analysis. New York, NY: Routledge, pp.130-143.

Husted, E. and Plesner, U. (2017). Spaces of open-source politics: Physical and digital conditions for political organization. Organization, vol. 24(5), pp.648-670.

Karvonen, A. and van Heur, B. (2014). Urban Laboratories: Experiments in Reworking Cities: Introduction. International Journal of Urban and Regional Research, vol. 38(2), pp.379-392.

Knight, F.H. (1921). Risk, uncertainty and profit. New York, NY: Houghton Mifflin.

Kuhlmann, S. and Rip, A. (2018). Next-Generation Innovation Policy and Grand Challenges. Science and Public Policy. Available at: DOI: 10.1093/scipol/scy011 [Accessed 22.03.2018] 
Le Pluart, J. (2016). Secret Innovation Lab Revealed. [online] IKEA. Available at: http://www.ikea.com/ms/en_US/this-is-ikea/ikea-highlights/IKEA-secretinnovation-lab/index.html [Accessed 27 Feb. 2018].

Leifer, E.M. (1991). Actors as observers: a theory of skill in social relationships. New York, NY: Garland.

Leijten, J., Butter, M., Kohl, J., Leis, M. and Gehrt, D. (2012). Investing in Research and Innovation for Grand Challenges. Brussels, Belgium: Joint Institute for Innovation Policy.

Locke, K., Golden-Biddle, K. and Feldman, M.S. (2008). Perspective-Making doubt generative: Rethinking the role of doubt in the research process. Organization Science, vol. 19(6), pp.907-918.

Mair, J. and Hehenberger, L. (2013). Front-Stage and Backstage Convening: The Transition from Opposition to Mutualistic Coexistence in Organizational Philanthropy. Academy of Management Journal, vol. 57(4), pp.1174-1200.

Mantere, S. and Ketokivi, M., 2013. Reasoning in organization science. Academy of Management Review, vol. 38(1), pp.70-89.

Mazzucato, M. (2013). The entrepreneurial state: debunking public vs. private sector myths. Anthem Press: London.

Mazzucato, M. (2018). Mission-oriented research \& innovation in the European Union: A problem-solving approach to fuel innovation-led growth. [online] Brussels, Belgium: European Commission, Directorate-General for Research and Innovation. Available at: https://publications.europa.eu/da/publication-detail//publication/5b2811d1-16be-11e8-9253-01aa75ed71a1/language-en [Accessed 09.08. 2018].

Padgett, J.F. and Powell, W.W. (2012). The problem of emergence. The emergence of organizations and markets. Princeton, NJ \& Oxford, England: Princeton University Press, pp.1-29.

Powell, W.W. and Steinberg, R. eds. (2006). The Nonprofit Sector: A Research Handbook. 2nd ed. New Haven, CT: Yale University Press.

Prewitt, K., 2006. Foundations. In: W.W. Powell and R. Steinberg, eds., The Nonprofit Sector: A Research Handbook, 2nd ed. Yale University Press, pp.355-377.

Puttick, R., Baeck, P. and Colligan, P. (2014). i-teams. The teams and funds making innovation happen in governments around the world. [online] London, England: Nesta and Bloomberg Philanthropies. Available at: https://www.nesta. org.uk/sites/default/files/i-teams_june_2014.pdf [Accessed 17.02.2018].

Realdania (2018a). BLOXHUB - Danmarks nye base for fremtidens byløsninger. [online] Realdania. Available at: https://realdania.dk/projekter/bloxhub [Accessed 20 Mar. 2018].

Realdania (2018b). Realdania. [online] Available at: http://www.realdania.org/en [Accessed 28.08.2018]. 
Rip, A. and Joly, P.-B. (2012). Emerging spaces and governance. A position paper for EU-SPRI. [online] Available at: http://www.euspri-forum.eu/key_missions/rip_ emerging_spaces_and_governance.pdf. [Accessed 22.02.2018]

Schot, J. and Steinmueller, E. (2016). Framing innovation policy for transformative change: Innovation policy 3.0. Brighton, England: SPRU Science Policy Research Unit, University of Sussex.

Schuyt, T.N.M. (2010). Philanthropy in European welfare states: a challenging promise? International Review of Administrative Sciences, vol. 76(4), pp.774-789.

Steinberg, R. (2006). Economic Theories of Nonprofit Organizations. In: W.W. Powell and R. Steinberg, eds., The Nonprofit Sector: A Research Handbook, 2nd ed. New Haven, CT: Yale University Press, pp.117-139.

Tõnurist, P., Kattel, R. and Lember, V. (2017). Innovation labs in the public sector: what they are and what they do? Public Management Review, vol. 19(10), pp.14551479.

United Nations General Assembly (2015). Transforming our world: the 2030 Agenda for Sustainable Development. [online] Available at: http://undocs.org/A/RES/70/1 [Accessed 19.07.2017] 